JUDr. Ing. Dalibor Nový, Ph.D.

Analýza systému vnitřních předpisů

a řídících aktů v ozbrojených silách

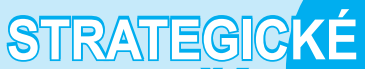
(Část 1.)

Vojenské rozhledy, 2013, roč. 22 (54), č. 4, s. 113-123, ISSN 1210-3292

\title{
The Analysis of Internal Regulations and Regulative Acts in Armed Forces
}

(Part I)

\section{Abstrakt:}

Článek rozebírá vztah mezi právními a vnitřními predpisy a akty ve státní správě se zaměrením na jejich hierarchii, množství a závaznost v ozbrojených silách. Ve vojenském prostředí se totiž uplatňuje široká škála a počet relativně autonomních služebních pravidel a postupů v podobě rozkazů, směrnic a pokynů. Ačkoliv každá interní úprava musí být v souladu s nadřazenými prameny práva, vztah mezi právní a vnitřní úrovní není jasný. Článek na vybraných př́kladech nastiňuje, že konzistentní systém vnitřních pravidel je založen především na průběžné a včasné aktualizaci, aby byl dodržen soulad s právním rádem.

\section{Abstract:}

This article analyzes the relation between legal and internal regulations and acts in public administration focusing on their hierarchy, quantity, liability in specific area of armed forces. There is a wide range and amount of relatively autonomous service regulations and official channels (internal orders, guidelines, advices). Although all internal regulations have to be in accordance with superior sources of law, relation between legal and internal level is not clear. Article exemplary outlines that consistent system of internal rules is based especially on running and immediate updates to meet harmony with legal code.

\section{Klíčová slova:}

Ozbrojené síly, Ministerstvo obrany, vnitřní úprava, právní řád, prameny práva, nařízení vlády, vyhlášky ministerstev, mezery v právu, rozkazy prezidenta republiky, rozkazy ministra, normativní výnosy, služební pomůcky, delegování pravomoci, slučitelnost a souladnost, stabilita a integrita, vojenské názvosloví.

\section{Key words:}

Armed forces, Department of Defence, internal regulations, legal code, sources of law, govermental directions, department orders, normative gaps, orders of president, orders of minister, normative edict rules, service guidelines, delegation of authority, compatibility and harmony, permanence and integrity, military terminology. 
Vydávání vnitřních předpisů a řídících aktů (příp. interních normativních aktů, instrukcí, pokynů apod.) je jev typický v soukromé, ale především ve veřejné sféře. Pokud jejich formu a existenci přímo neukládá právní předpis, odvíjí se jejich názvosloví, četnost, hierarchie i podoba zpravidla od charakteru organizace, která je vydává.

Ozbrojené síly ČR rezortně spravované Ministerstvem obrany a podřízené prezidentu republiky jako jejich vrchnímu veliteli zaujímají v tomto směru zvláštní pozici. Vojenský život byl vždy více než jiné oblasti státní správy osnován vojenskými řády, služebními předpisy a rozkazy coby akty s normativním, individuálním i plánovacím obsahem.

\section{Úvod}

Ideální požadavek na harmonii a provázanost mezi jednotlivými regulativy lidského chování naráží na ustavičné napětí jak v množině vnitřních předpisů a řídících aktů, tak v množině obecně závazných pramenů práva, které přestože stojí v permanentním konfliktu, mají být referenčním kritériem konformity vnitřní normotvorby.

Zásada směrodatná pro obecně závazné prameny práva však platí i pro vnitřní předpisy a řídící akty: izolovanou kvalitu (aktuálnost, adekvátnost) každého vnitřního regulativu relativizuje (devalvuje) jeho pozice v nepřeberné množině ostatních vnitřních regulativů. Pro představu kvantity vnitřních řídících aktů v celém rezortu MO (zvl. ozbrojených silách) lze využít elektronické verze Věstníku Ministerstva obrany (EPINAV), z níž vyplývá přehled vnitřních předpisů, vojenských předpisů a služebních pomůcek. V rezortu MO v polovině r. 2013 platilo 39 rozkazů prezidenta republiky (RPR), 326 rozkazů ministra obrany (RMO), 172 normativních výnosů MO (zahrnujících i dřívější nařízení náčelníka GŠ AČR), 1007 vojenských předpisů a 200 služebních pomůcek. Databáze mimoto registruje stovky různých jiných dokumentů, např. každoroční přehled platných rezortních mezinárodních smluv a správních dohod, vnitřních aktů, přetisky důležitých zákonů, vyhlášek a usnesení Parlamentu ČR, sdělení a oznámení funkcionářů ministerstva, opatření či zásady ministra apod. Poněvadž EPINAV generuje platné dokumenty odděleně i mezi ostatními, formálně již neplatnými, lze v úhrnu vyhledat cca 80 RPR, 900 RMO, 370 NVMO včetně dřívějších NNGŠ. Počet záznamů od r. 1950 dodnes, včetně odkazů na další vojenské předpisy a služební pomůcky, se blíží číslu 5200.

Předmětem zkoumání takto početného a diverzifikovaného systému vnitřních předpisů a dalších řídících aktů, především jde-li o jeho výstavbu, tvorbu a zpřístupnění adresátům, jejichž chování mají interní akty ovlivňovat, jsou vzájemné vazby mezi jednotlivými prvky, které lze nazírat z těchto hledisek:

1. Vztahy v rámci hierarchie vnitřních předpisů a řídících aktů, které se odvíjejí od pravomoci tyto předpisy a akty vydávat. Je třeba vzít v potaz, že hierarchie není vzhledem ke kombinaci vztahů přímého a odborného řízení přísně vertikální.

2. Respektování souladu formy a obsahu, tj. zdali vnitřní předpisy odpovídají požadavku na normativnost a obecnost a naproti tomu zda řídící akty jsou individuální (konkrétní) pokyny navazující přímo na právní anebo na vnitřní předpisy.

3. Soulad vnitřních předpisů a řídících aktů s prameny práva, v nichž by měl být obsažen právní základ pro uskutečňování příslušné administrativní činnosti. Soulad s prameny práva je ovlivňován faktorem času i obsahu. 
4. Konzistentní pravidla pro tvorbu a vydávání vnitřních předpisů, příp. řídících aktů, která musejí v zájmu udržování souladu s prameny práva současně obsahovat účinné mechanismy nejen pro aktualizaci (novelizaci) předmětné vnitřní úpravy, ale i zásady pro soustavnou kontrolu vnitřní normotvorby.

5. Publicita, tj. přístupnost vnitřních aktů řízení adresátům jako nezbytný předpoklad, aby př́islušné interní regulativy mohly být považovány za závazná pravidla chování pro osoby, jichž se týkají.

Pozn.: Z di̊vodu rozsahu se tento príspěvek věnuje pouze bodi̊m 1. až 3., následující budou pojednány v některém z př́štích čísel Vojenských rozhledi̊.

\section{Vztahy v rámci hierarchie vnitřních řídících aktů}

Navzdory mnohočetnosti a nepřebernosti vnitřních řídících aktů v ozbrojených silách, resp. v rezortu MO, lze ohraničit množiny vnitřních předpisů a řídících aktů, jež schvaluje a vydává

$\square$ vrchní velitel ozbrojených sil (RPR a základní řády),

$\checkmark$ vláda (usnesení a kontrasignace aktů prezidenta republiky),

- ministr (organizační řád, RMO, rozhodnutí, úkolový list),

přímo podřízení ministra (NVMO),

$\checkmark$ další vedoucí zaměstnanci ministerstva nebo ozbrojených sil (vojenské předpisy, služební pomůcky, vojenské doktríny i jiné akty: např. přímo ze zákona ředitel Úřadu pro obrannou standardizaci, katalogizaci a státní ověřování jakosti schvaluje Český obranný standard).

Z pravomoci různých řídících stupňů (činitelů) schvalovat předpisy a akty určitého názvu a formy se sice odvíjí jejich nadřazenost a podřazenost a tedy i vertikální hierarchie, ale k náčrtu úplné a homogenní sítě vztahů to nestačí. Vertikální osu vztahů přímého řízení, kdy vydaný akt zavazuje jen subjekty organizačně podřízené schvalujícímu funkcionáři, totiž horizontálně protínají tzv. vztahy odborného řízení, kdy zmocnění funkcionáři zavazují (úkolují) i prrímo nepodřízené subjekty. Nelze pak spolehlivě vyšetřit, který vnitřní předpis či řídící akt se formálně (vertikálně) nadřazuje či podřazuje jinému, a který je navzdory předpokládané vertikální hierarchii odborně (horizontálně) ovlivňován obsahem jiného.

Pokud však různí vedoucí funkcionáři ministerstva či ozbrojených sil v linii odborného řízení vydávají akty řízení, které významově a obsahem de facto nahrazují formální RMO či NVMO, avšak nesdílejí srovnatelnou proceduru vzniku a publikace vnitřního předpisu, jde o negativní jev. Místo aby tito funkcionáři jako gestoři příslušné odborné oblasti iniciovali vznik regulérního vnitřního předpisu, nesystémově obcházejí proceduru přípravy, připomínkování a schvalování tím, že bez jakékoliv konzultace vydají nějakou směrnici, nařízení či metodický pokyn zavazující po odborné linii přímo nepodřízené adresáty.

Představa, aby si některé dokumenty nemající formu vnitřního předpisu nárokovaly všeobecnou závaznost jen proto, že ministr přenesl (delegoval) část své monokratické (odborné) pravomoci na podřízeného, se s požadavkem na transparentní hierarchii vnitřních řídících aktů také příliš neslučuje. Netýká se to pouze náměstků, jimž přísluší 
výhradně forma vnitřního předpisu NVMO, a přesto setrvačně vydávají různá odborná nařízení, směrnice, prozatímní odborné pokyny aj., ale i jejich podřízených, kteří by vnitřní př̌edpisy závazné pro všechny neměli vydávat vůbec.

Za př́klad lze dát ředitele bývalé sekce vyzbrojování MO (dnes Národní úřad pro vyzbrojování MO), který podle ministrem schváleného Všeob-P-4 Hospodaření s majetkem v rezortu MO (2004) plní funkci správce majetkového uskupení pro nehmotné výsledky výzkumné a obdobné činnosti (6.1) a ocenitelná práva (6.3). Na základě toho v r. 2008 vydal Metodické pokyny pro hospodaření s nehmotným majetkem majetkových uskupení 6.1 a 6.3 v rezortu MO (čj. 102414-18/2004/DP-5888) určené pro vedoucí zaměstnance organizačních celků MO, materiální orgány všech velitelských stupňů a uživatele nehmotného majetku, kteř́ jsou povinni se jimi ř́́dit, a závazné pro všechny organizační celky MO, včetně jimi ř́zených útvarů při zajišštování oprávněnosti užívání nehmotného majetku.

V tomto př́ípadě se zjevně jedná o nesprávný postup, protože jednotný výkon každé odborné činnosti by v zájmu přehledné hierarchie vnitřních řídících aktů měl zastř̌ešovat vnitřní normativ připravený odborným funkcionářem zodpovědným za př́íslušnou administrativní oblast, avšak schválený a vydaný vrcholným činitelem ministerstva či ozbrojených sil (např. ministrem či prezidentem), který má pravomoc uložit všem podřízeným dodržování takového vnitřního předpisu jako závazného regulativu.

Za tentokráte následováníhodný př́íklad lze dát opět ředitele bývalé sekce vyzbrojování MO, který podle Všeob-P-4 odpovídá také za zabezpečení ochrany a hospodaření státu s předměty průmyslového vlastnictví z výsledků obranného výzkumu a vývoje. Činnost však neupravuje jím vydaný metodický pokyn, ale podle pravidel v tehdy platném RMO č. 56/1993 řádně připravený, připomínkovaný a ministrem schválený RMO č. 1/2009 - Předměty průmyslového vlastnictví v působnosti MO.

Lze usuzovat, že druhová rozmanitost a počet vnitřních předpisů by měly klesat, pokud je v rámci hierarchie vertikálních ř́́dících vztahů budou schvalovat a vydávat jen vrcholní rídící činitelé ozbrojených sil, resp. rezortu MO. Naopak druhová a početní skladba vnitřních předpisů se zřejmě zvýší, jakmile bude jejich schvalování a vydávání svěřeno, resp. v podobě tzv. šedé legislativy tolerováno funkcionářům pověřeným odborným ř́izením vybrané administrativní činnosti. Perspektivou posílení přehledné hierarchie vnitřních aktů řízení je postupné rušení tzv. šedé legislativy a její nahrazení formálními vnitřními předpisy (nap̌r. takto byla již zrušena a transformována souvislá série odborných nařízení sekce personální $\mathrm{k}$ různým pracovněprávním a služebněprávním otázkám).

\section{Rozpor formy a obsahu předpisů a aktư}

Přestože vnitřní předpisy by měly typizovat obecnost a normativnost, kdežto řídící akt je individualizován konkrétním úkolem pro konkrétního adresáta, v praxi jsou jejich forma a obsah často v protikladu. Př̀ volbě optimální formy zavazujícího aktu běžně dochází $\mathrm{k}$ prolínání normativních vnitřních předpisů $\mathrm{s}$ individuálními řídícími akty. Obsahově totožný záměr (projev vůle) býval vyjadřován rozličně v různých epochách.

Př́íkladem neustálenosti jsou organizační i pracovní řád, které dnes nemají formu vnitřního předpisu, ač dříve do ní byly vtěleny. [1] RPR jako normativní akt leckdy 
zprostředkovával vydání či změnu jiného služebního předpisu, v určitých prrípadech registrovaného ve Sbírce zákonů jako rezortní právní předpis. [2] RMNO i NNGŠ sloužily jen jako formální nosiče směrnic podřizeného funkcionáře. [3]

$\mathrm{K}$ nepředvídatelným proměnám forem dochází během řetězení obsahově provázaných aktů, kdy se např. individuální rí́dící akt jako je rozhodnutí nebo úkolový list ministra uložením úkolu podřízenému (obvykle náměstkovi) transformuje $\mathrm{v}$ akt normativní, je-li úkol splněn vydáním vnitřního předpisu. Praxe pak vytváří překvapivé disproporce: např. organizační změny v rezortu MO byly v r. 2009 zajištěny toliko metodickým pokynem, [4] kdežto negativní dopady reformy Armády ČR v r. 2002 zmírňoval obsahově souměřitelný RMO; [5] jiným př́íkladem je použití vojáků k plnění úkolů Policie ČR podle př́islušného nařízení vlády, kdy ojediněle bylo provedeno formou RMO, [6] zpravidla však méně formalizovanými ř́dícími akty ministra.

Uzlovým, pro vojensky organizované soustavy typickým pojmem a př́íkladem rozporu forem a obsahu vnitřních aktů řízení je rozkaz. Četná podobenství rozkazu zřetelně indikují obecnou rozbíhavost forem a obsahu vnitřních předpisů a řídících aktů, která může vyvolávat neustálené, nahodilé a nesouměrné vazby. Rozkaz totiž může mít podobu a úlohu vnitřního předpisu, plánovacího dokumentu i individuálního ř́́dícího aktu. Někdy je jeho definice ryze účelová: např. čl. 93 předpisu Všeob-P-35 Vnitřní kontrola a vyřizování petic a stížností v působnosti MO míní rozkazem služebního orgánu jakýkoli akt ř́zení nebo velení, tj. např. nařízení, opatření či směrnici.

Napohled jasný § 7 odst. 2 zákona č. 219/1999 Sb., o ozbrojených silách České republiky, podle nějž ministr $\mathbf{k}$ zabezpečení úkolů armády vydává rozkazy, které jsou závazné pro vojáky v činné službě, se v kontextu zavádějící interní terminologie a nevhodné interpretace stává doslova zmatečnou větou.

A. RMO jako vnitřní předpis schvaluje výhradně ministr, který je nadřízený vojákům Armády ČR, Vojenské policie a Vojenského zpravodajství, ale i civilním zaměstnancům. Ačkoliv se RMO vůči všem prosazuje jako závazný vnitřní předpis, ve světle $\$ 7$ odst. 2 zákona č. 219/1999 Sb. není zřetelné, zdali ministr může pomocí RMO rrídit a úkolovat i občanské zaměstnance, když zákon závaznost jeho rozkazu zužuje jen na vojáky v činné službě (před novelou č. 546/2005 Sb. dokonce obecně na vojáky). Ustanovení v zákoně tak v podstatě legitimuje každého, kdo není vojákem v činné službě, k odepření poslušnosti RMO pro nedostatek formy řízení. Je zřejmé, že v zájmu odstranění výkladových pochybností měl být pro všeobecně závazný vnitřní předpis ministra zaveden jiný pojem než rozkaz.

B. Rozkaz jako nástroj krátkodobého plánování vydávají podle čl. 249. Zákl-1 v pracovních dnech velitelé útvarů a rot (baterií) na příštích 24 hodin. Obsahuje zejména výpisy z rozkazů nadřízených, zařazení do služeb a směn, bojové pohotovosti a dosažitelnosti, pokyny pro zaměstnání následujícího dne, vyhlášení udělených odměn a uložených trestů. Rozkaz se vyhlašuje před nastoupenou jednotkou, poté se provádí bojové rozdílení. Hromadné řízení tímto harmonogramem činnosti je v pojetí Zákl-1 poplatné kasárenskému režimu vojenského útvaru, avšak setrvačně se adaptovalo i v organizačních strukturách ministerstva. Úloze předjímané v Zákl-1 se tzv. vnitřní rozkaz vydávaný s různou periodicitou (týdně, měsíčně) blíží jako sumář pracovních (služebních) cest, udělených dovolených, ohlášených neschopností k práci (službě), jmenovaných komisí aj. Nařizovací a plánovací účel však postrádá, pokud jej velitel (náčelník, ředitel) vydává zpětně, víceméně jen k rekapitulaci a zúčtování uplynulého období. 
C. Rozkaz jako individuální akt řízení nejvěrněji vystihuje styl komunikace mezi nadřízeným a podřízeným. Rozkaz je nástrojem velení, zvláštním projevem vůle velitele (náčelníka) a tzv. nedílné velitelské pravomoci. [7] Nadřízení mají dle čl. 42. Zákl-1 právo dávat podřízeným rozkazy a musejí kontrolovat jejich plnění. Podřízení jsou povinni rozkazy nadřízených plnit včas a jak nejlépe dovedou. Rozkazy se vydávají přímo nebo služebním postupem, ústně nebo písemně. Jako projev vůle, jímž se závazně ukládá určitá povinnost (úkol), musí být rozkaz stručný a jasný a obsahovat údaje nezbytné k jeho splnění (doba, výčet určených sil a prostředků). Rozkazující je povinen vytvořit podmínky pro přesné a správné splnění rozkazu, a každý podřízený plně odpovídá za důsledky jeho neuposlechnutí (čl. 64. - 67. Zákl-1). Rozkaz nadřízeného (velitele) ve smyslu aktu řízení je podle judikatury (rozsudek Nejvyššího správního soudu z 18. srpna 2011, čj. 3 Ads 58/2011-61) analogicky srovnatelný s pokynem zaměstnavatele ve smyslu $\$ 301$ odst. 1 písm. a) zákoníku práce č. 262/2006 Sb., jimž zaměstnavatel realizuje svou dispoziční pravomoc. Pouze proti rozkazu jako individuálnímu pokynu lze tak zřejmě uplatnit obranu vojáka, je-li rozkaz zjevně rozporný s právním předpisem či směřuje ke spáchání trestného činu, kterou skýtá $§ 48$ odst. 2 zákona č. 221/1999 Sb. Stejné pojetí rozkazu by se týkalo i kvalifikace neuposlechnutí rozkazu jako kázeňského přestupku nebo trestného činu.

\section{3. Časový a obsahový soulad vnitřních řídících aktů s prameny práva}

Ve vztahu dvou či více soustav normativních (ř́íících) aktů, kdy jedna je nadřazená druhé, se předpokládá neustálý vzájemný soulad (bezrozpornost). Problém nastává již rovině pramenů práva, poněvadž zákonné zmocnění k vydání prováděcího právního předpisu nebo podnět k vydání nějaké vnitřní úpravy nejsou svázány s časovým mezníkem, dokdy musí být zákon proveden, resp. aplikován v praxi. Prováděcí právní předpisy by přitom měly sledovat vznik zákona a působit bez zbytečného prodlení, nejlépe již k datu účinnosti zákona. Včasná a neodkladná musí být i opatření vtělená do vnitřních předpisů nebo řídících aktů, a neměla by se jakkoliv dostávat do konfliktu s právní úpravou.

Prodlení s vydáním prováděcího právního předpisu i pozdní vydání nebo nevydání vnitřního předpisu nebo řídícího aktu aplikaci zákona ochromuje. Zákon přitom o potřebě interní úpravy nemusí výslovně hovořit, postačí, že předmětnou právní materii v podrobnostech neupraví, s konkludentním předpokladem vytvoření funkčního prostředí pro aplikaci zákona až uvnitř správního aparátu.

Obvyklý legisvakanční interval mezi platností a účinností právního předpisu tak neslouží jen tomu, aby se dotčení adresáti mohli s novou regulací seznámit a nanečisto si osvojit práva a povinnosti předtím, než začnou závazně ovlivňovat jejich chování, ale vytváří časový prostor také pro kvalifikované adresáty jako vykonavatele státní mocenské vůle. Ti musejí jako zprostředkovatelé zavčas přichystat řádné materiálnětechnické, organizační, finanční a personální zázemí k plnohodnotné implementaci právního předpisu již $\mathrm{k}$ datu jeho účinnosti. Vytvoření adekvátního prostředí nemusí záležet jen na vydání prováděcího právního či průvodního vnitřního předpisu, ale třeba na zprovoznění nějakého systému či funkcionality pořízených komerčně. [8] 
Pokud jde o dobu potřebnou ke změně uvnitř správního aparátu, žádoucí efekt nemusí zaručit ani významná časová tolerance zákonodárce k přizpůsobení vnitřního prostředí. Jako prríklad lze na prvním místě zmínit vnitřní systém finanční kontroly podle zákona o finanční kontrole č. 320/2001 Sb., který byl v rezortu MO zaveden se zpožděním i navzdory benevolentnímu půlročnímu odkladu nejpozději do konce června r. 2002 (\$ 32 odst. 3 zákona). Až 18. listopadu 2002 vyslal RMO č. 42/2002, Organizace finančního zabezpečení a hospodaření s finančními prostředky v působnosti MO, obecný signál, že vedoucí zaměstnanci jsou dle svých kompetencí povinni zajistit fungování vnitřního kontrolního systému. Klíčové RMO č. 5/2003 a NVMO č. 16/2003 vyšly až na jaře př́ǐstího roku, ovšem na vydání vyhlášky č. 416/2004 Sb. formálně nezareagovaly dodnes.

Dalším př́íladem časového skluzu i formálního chaosu je úprava spisové a archivní služby. Aktuální RMO č. 11/2010, Spisový řád rezortu MO, a NVMO č. 12/2010, Spisová služba, reflektují elektronizaci úkonů podle zákona č. 300/2008 Sb. a nahrazují předpis Adm-1-1 Spisová a archivní služba v rezortu MO (2008). Ten byl však vydán až čtyři roky po účinnosti zákona o archivnictví a spisové službě č. 499/2004 Sb., resp. \$ 66 odst. 1, podle nějž určení původci vydají spisový řád; mezitím se běžně používal předešlý RMO č. 9/2001 - Zásady spisové služby a archivnictví v rezortu MO, který se dovolával již neplatného zákona o archivnictví č. 97/1974 Sb.

Oblastí chronického nesouladu vnitřní úpravy s prameny práva je zadávání veřejných zakázek. Přestože rezort MO měl vlastní pravidla pro zadávání veřejných zakázek dřive než celý stát, [9] současný zákon č. 137/2006 Sb. čekal na regulérní vnitřní úpravu déle než dva roky, až do vydání RMO č. 39/2008 - Zadávání veřejných zakázek v rezortu MO. Mezidobí překlenovaly různé prozatímní směrnice a nařízení, [10] přestože formálně platil RMO č. 2/2005 - Úplatné nabývání majetku a pořizování stavebních prací a služeb v rezortu MO, výslovně vydaný k zákonu o veřejných zakázkách č. 40/2004 Sb.

Ani po významných novelách zákona o veřejných zakázkách v letech 2011 a 2012 (viz zákon č. 258/2011 Sb. implementující evropskou směrnici 2009/81/ES o veřejných zakázkách v oblasti obrany a bezpečnosti a zákon č. 55/2012 Sb.) nevznikl v rezortu MO prováděcí právní předpis nebo vnitřní předpis, který by na tyto novely účinně a včas zareagoval.

Př́́kladem je změněné zmocnění v $\$ 159$ odst. 2 zákona, které Ministerstvu obrany ukládá vydat vyhlášku k provedení nového znění $\S 17$ písm. q) a $§ 18$ odst. 4 písm. h). Na základě toho tedy ministerstvo bezodkladně mělo alespoň aktualizovat vyhlášku č. 274/2006 Sb. vydanou k původnímu znění zákona. Vyhláška však dodnes nijak novelizována nebyla, čímž paradoxně provádí již zrušená ustanovení zákona, resp. ustanovení s diametrálně odlišným obsahem. Přizpůsoben novelám č. 258/2011 a č. 55/2012 Sb. nebyl ani RMO č. 39/2008 (již zrušený aktuálním RMO č. 52/2013 - Nabývání majetku $\mathrm{v}$ rezortu $\mathrm{MO}$ ).

Jak dále znázorní další signifikantní př́íklady, důsledkem nesouladné právní a vnitřní regulace může být odpírání ústavou i zákony zaručených práv a snižování právní jistoty jednotlivce. 


\subsection{Pravidla činnosti odborného poradního orgánu ve výzkumu a vývoji}

Každý zákon hned v zárodku paralyzuje svoji funkci, pokud určitou součinnost s adresáty podmiňuje vydáním konkrétního vnitřního předpisu, avšak nezaručuje veřejnou kontrolu či obranu adresátům, když takový předpis vydán není anebo je vydán ve zřejmém rozporu s právním předpisem. Problematický je $§ 21$ odst. 4 zákona o podpoře výzkumu a vývoje č. 130/2002 Sb., podle nějž složení a pravidla činnosti odborného poradního orgánu a způsob nakládání s údaji v návrzích projektů upraví poskytovatel vnitřním předpisem, který zveřejní nejpozději při vyhlášení veřejné soutěže. Žádná bližší hlediska však zákon nepředestírá ani nepřiznává prostředky nápravy uchazečům o poskytnutí podpory, jestliže by poskytovatel svoji povinnost zanedbal. Veřejná soutěž podle zákona č. 130/2002 Sb. je totiž (na rozdíl od zadávání veřejných zakázek v režimu zákona č. 137/2006 Sb.) prosta jakéhokoliv formálního správního přezkumu či dohledu.

\subsection{Omezení sdružování na hraně ústavnosti}

Restrikce sdružovacího práva v § 45 odst. 2 zákona č. 221/1999 Sb. evidentně koliduje s čl. 20 odst. 3 Listiny základních práv a svobod. Vojáci z povolání nesmějí být členy politické strany, politického hnutí a odborové organizace (§ 45 odst. 1), avšak mohou se sdružovat v profesních sdruženích, jejichž činnost zabezpečí dohoda o spolupráci s ministerstvem a vnitřní norma ministerstva. Dikce $\S 45$ odst. 2 zpochybňuje ústavní základ sdružovacích práv ne tím, že něco zakazuje jako $\$ 45$ odst. 1, ale že klade podmínky, jejichž dosažení závisí jednostranně na uvážení vykonavatele zákona. Blíže nespecifikovaná vnitřní norma ministerstva totiž vstoupila v účinnost až 27. března 2006, tj. o šest let později než zákon, a to ve formě RMO č. 5/2006 - Spolupráce s profesními sdruženími v působnosti MO. Profesním sdružením se míní občanské sdružení sestávající výhradně vojáků z povolání k uspokojování jejich oprávněných zájmů souvisejících s výkonem služby, které uzavřelo písemnou dohodu o spolupráci s ministerstvem a splňuje podmínky zákona o sdružování občanů č. 83/1990 Sb. Tento zákon ovšem výkon sdružovacího práva nikdy nepodmiňoval žádným povolením a registraci občanského sdružení nesvazoval s jinými, než jen tímto zákonem danými limity. Výkon sdružovacích práv lze sice cestou zákona omezit, leč jistě ne opatřeními záležejícími vyloženě na vůli vykonavatele zákona taková opatření přijmout. Několikaletý prostoj mezi zákonem č. 221/1999 Sb. a RMO č. 5/2006, který teprve předestřel náležitosti dohody o spolupráci, jasně ukazuje, že vydání vnitřní normy ministerstva bylo zcela mimo dispozici subjektů, jejichž činnost měla legalizovat.

\subsection{Stejnokroj nedostupný pro válečné veterány}

Rozpor, který byl na základě podnětů dotčených adresátů dodatečně zhojen, vyplynul z § 31 odst. 3 zákona č. 219/1999 Sb. Podle něj vojenský stejnokroj a odznaky nosí jen vojáci v činné službě, avšak při slavnostních př́iležitostech ho mohou nosit i vojáci mimo činnou službu a další osoby, kterým to povolil služební orgán. Podle RMO č. 36/2002 - Průběh služby vojáků z povolání lze takové nošení povolit, trval-li služební 
poměr alespoň 10 let či 5 let, konal-li voják minimálně 6 měsíců službu v zahraničí. Doba trvání služebního poměru se týkala i válečných veteránů, pro něž však byla obtížně splnitelnou, ne-li zcela nesplnitelnou podmínkou. Teprve RMO č. 18/2007 měnící RMO č. 36/2002 odstranil kritérium doby trvání služebního poměru, a to pro válečné veterány, kteří jsou nositeli osvědčení podle $\S 1$ odst. 1 písm. a) až f) zákona č. 255/1946 Sb. a dosáhli vojenské hodnosti.

\subsection{Hromadná retroaktivita v pracovněprávních vztazích}

Zpětnou účinnost (retroaktivitu) vůči dotčeným zaměstnancům vyvolal čl. 4 RMO č. 20/2008 - Jmenování občanských zaměstnanců na vedoucí pracovní místa v rezortu MO, podle nějž se pracovní poměry vedoucích zaměstnanců založené pracovní smlouvou považují dnem účinnosti zákona č. 362/2007 Sb. za založené jmenováním. Zákon však nabyl účinnosti 1. ledna 2008 a přeměnu pracovních poměrů nepředpokládal, zatímco RMO vstoupil v účinnost až 30. června 2008. Je nanejvýš sporné, zdali lze hromadně vnitřním předpisem (a nadto zpětně) změnit režim smluvní na jmenovací, když se standardně jedná o právní úkony mezi konkrétními osobami. Jmenování a odvolání vedoucího zaměstnance totiž může provádět výlučně ministr a pracovní poměr vzniká dnem, který byl uveden jako den jmenování.

\subsection{Spor o výlučnou očkovací pravomoc}

Doslova normativní a exekutivní anarchii rozpoutala počátkem ledna 2010 ,,povinnost" tisíců vojáků a zaměstnanců podrobit se očkování proti tzv. prasečí chřipce. Zdánlivě soběstačnou právní úpravu ochrany veřejného zdraví v ozbrojených silách podle $\S 83$ odst. 1 zákona č. 258/2000 Sb. zrelativizovala zmatečná aplikační praxe. Povinnost podrobit se očkování uložil hlavní hygienik MO rozhodnutím (čj. 13-6/20103696) podle $\S 83$ odst. 1 a $\S 69$ odst. 2 zákona č. 258/2000 Sb. a podle $§ 94$ zákona č. 221/1999 Sb. s tím, že vakcinace je v rezortu obrany povinná a osoby a vojenská zdravotnická zařízení se mimořádnému opatření musejí podřídit, jinak se vystavují riziku restriktivních opatření. Náčelník GŠ AČR souběžně vydal Nařízení k provedení mimořádného opatření proti pandemické chřipce v r. 2010 (čj. 13-5/2010-3696) odvolávaje se na usnesení vlády č. 1413 z 19. listopadu 2009, které se týkalo vakcinační strategie pro očkování vakcínou proti chřipce způsobené virem Pandemic A(H1N1) 2009 v ČR a jímž vláda schválila seznam subjektů poskytujících veřejné služby důležité pro zajištění chodu státu, včetně Ministerstva obrany a Armády ČR.

Do problému se jako první vložil prezident republiky, nikoliv ovšem jako vrchní velitel ozbrojených sil, ale docela občansky. [11] Poté věc řešila Bezpečnostní rada státu a na konec vláda, která na základě právního rozboru dospěla k závěru, že vyhlášení opatření podle zákona č. 258/2000 Sb. je v kompetenci jedině hlavního hygienika ČR jako orgánu Ministerstva zdravotnictví, který jako jediný smí vyhlásit takové mimořádné opatření a na jehož rozhodnutí závisí i postup v rezortu MO. Usnesením č. 164 z 22. února 2010 pak vláda přistoupila $\mathrm{k}$ dobrovolnému očkování všech pojištěnců starších tří let a hlavní hygienik MO nařídil (rozhodnutí čj. 103-49/2009/DP-3696) 
vojenským zdravotnickým zařízením očkovat jen ty vojáky z povolání a občanské zaměstnance, kteří o to požádají.

\subsection{Pozastavení účinnosti právního předpisu vnitřním aktem}

Diskutabilní způsob aplikace, resp. suspenzace (pozastavení účinnosti) právních předpisů z důvodů ryze vnitřního charakteru umožňuje výkon státní správy na území vojenských újezdů. Ten ovlivňují také místní právní předpisy územních samosprávných celků, konkrétně krajů, ale i vnitřní předpisy jiných státních orgánů. Újezdní úřad se tak př̀i plnění správních úkolů řídí i obecně závaznými vyhláškami a nařízeními kraje a metodickými pokyny správních úřadů, do jejichž odborné gesce výkon státní správy náleží. Svérázný interní postup, zjevně rozporný a neslučitelný např. se standardním zákonným dozorem podle $\S 81$ až 84 zákona o krajích č. 129/2000 Sb., upravuje RMO č. 24/2002 - Činnost ve vojenských újezdech. Jde o námitku rozporu a dočasnou sistaci právních a vnitřních předpisů, podle níž pokud by se obecně závazná vyhláška či nařízení kraje nebo metodický pokyn příslušného správního úřadu dostaly do rozporu s posláním vojenského újezdu, oznámí to přednosta újezdního úřadu neprodleně příslušnému úřadu, služebním postupem navrhne jednání s věcně příslušným ústředním správním orgánem a realizaci sporného opatření odloží do konečného rozhodnutí.

\section{Závěr}

V tomto příspěvku byly uvedeny a na konkrétních příkladech kriticky znázorněny slabé stránky v systému vnitřních předpisů a řídících aktů používaných v ozbrojených silách i v rezortu MO. Některé nedostatky jsou natolik závažné, že chaotickou materii a vztahy mezi vnitřními regulativy vůbec nedovolují nazvat systémem. Lze shrnout, že:

1. Hierarchie vnitřních řídících aktů není žádnou právní ani vnitřní normou výslovně stanovena. Jejich nadřazenost a podřazenost lze odvozovat jen od vertikálních stupňů činitelů řídících ozbrojené síly, resp. celý rezort MO. Tuto hierarchii však protínají a destabilizují horizontální vztahy odborného řízení, v nichž vznikají řídící akty nesplňující formální a procedurální náležitosti vnitřního předpisu, ale osobující si plošnou celorezortní závaznost (tzv. šedá legislativa).

2. K nerespektování úlohy aktů normativních a individuálních dochází tehdy, pokud je obsahově totožný projev vůle vyjadřován ve formě normativního předpisu i individuálního řídícího aktu. Zmatečnou rozbíhavost formy a obsahu dokládá institut (pojem) rozkazu, který má podobu vnitřního předpisu, individuálního pokynu i plánovacího aktu.

3. Rozpor vnitřních řídících aktů s prameny práva vzniká hlavně v důsledku pozdní reakce interních předpisů na změnu (novelizaci) právního předpisu. Prodlení, kdy se setrvačně postupuje podle zastaralé vnitřní úpravy, nezř́ídka trvá i několik let. Jestliže prováděcí právní předpis nebo vnitřní předpis nejsou vůbec vydány anebo včas aktualizovány a uvedeny do souladu s nadřazeným pramenem práva, prohlubuje se nepřehledný stav regulace a chaotické aplikační prostředí. Snižuje se rovněž konzistence a srozumitelnost úpravy a deformují se zákonné pod- 
mínky v neprospěch adresáta. Rizikovým důsledkem je nepřípustné, až neústavní zpř́ísňování způsobů aplikace práva.

Náměty a doporučení, jak alespoň zmírnit předestřené nedostatky, budou uvedeny v pokračování tohoto příspěvku.

\section{Poznámky k textu a literatura:}

[1] Viz RMO č. 35/1992, Vydání Prozatímního organizačního řádu FMO v míru, a služební (bojové) řády z r. $1985 V \check{s} e o b-\check{R}-10$, Organizační řád FMNO v míru, a V̌̌eob-Ř-11, Organizační řád FMNO za branné pohotovosti státu. V̌̌eob-P-10, Pracovní řád pro občanské pracovníky vojenské správy (1989).

[2] $R P R C \check{c} .10 / 1983$, Základní ustanovení o průběhu vojenské činné služby vojáků v základní (náhradní) službě a v záloze zbrojených sil ČSSR v míru (Zákl-P-1), RPR Č. 17/1992, Vydání Základního řádu ozbrojených sil ČSFR, RPR č. 19/1992, Vydání Cvičebního řádu ozbrojených sil ČSFR.

[3] RMNO č. 35/1989 obsahoval Směrnice náčelníka vyzbrojování a technického zabezpečení ČSLA pro kontrolu a hodnocení stavu výzbroje a techniky v ČSLA; NNGك̌ č. 014/1981 zastřešoval Směrnice náčelníka hlavní stavební a ubytovací správy - zástupce ministra národní obrany o postupu př̀ projednávání a vydávání stanovisek vojenské správy k civilní investiční výstavbě a územně plánovací činnosti.

[4] K úkolovému listu ministra č. 419/2009-1140 z 25. června 2009 vydal náměstek Metodický pokyn k provádění personální práce s vojáky z povolání a občanskými zaměstnanci při zajišrování organizačních změn z důvodu restrikcí v oblasti personálních a mandatorních výdajü rozpočtu kapitoly MO na r. 2010 (čj. 57-14/2009-7542 z 3. července 2009).

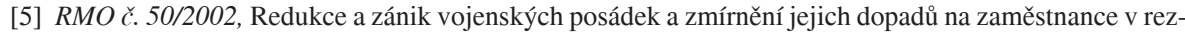
ortu $\mathrm{MO}$, obce a regiony.

[6] $R M O \check{c}$. 27/2000, Použití vojáků z povolání a vojenské techniky k plnění úkolů pořádkové služby Policie České republiky.

[7] Blíže např. viz ŠEDIVÝ, V. Právní rád v rukou velitele. Praha: Naše vojsko - Knižnice vojenských př́ruček, svazek 74, vydání 3., doplněné a přepracované, 1987, s. 65-75.

[8] Např. zákon č. 300/2008 Sb., o elektronických úkonech a autorizované konverzi dokumentů, od 1. července 2009 uložil orgánům veřejné moci, vedou-li spisovou službu elektronicky, zř́́dit tzv. datové schránky; zákon č. 227/2000 Sb., o elektronickém podpisu, předpokládá existenci elektronické podatelny, jejímž prostřednictvím orgán veřejné moci příslušné datové zprávy přijímá a odesílá.

[9] Nařízení NGŠ ČSA č. 47/1991, Směrnice pro výběrové řízení v rezortu FMO, až poté usnesení vlády č. 458 z 24. června 1992 k širšímu uplatnění veřejného zadávání při obstarávání zakázek financovaných z veřejných prostředků, s odstupem zákon č. 199/1994 Sb., o zadávání veřejných zakázek.

[10] První a provizorní normativní reakcí na novou úpravu bylo od 1. srpna 2006 účinné Prozatímní odborné nařízení pro úplatné nabývání majetku a nákup služeb podle zákona č. 137/2006 Sb.

[11] Prohlášení z 27. ledna 2010 znělo:

„Povinné očkování vojáků a občanských zaměstnanců proti pandemické chřipce, a to právě nyní, pokládám za věc mimorádně spornou, ne-li neprìjatelnou. Mělo by to jisté oprávnění v akutní epidemické situaci, ale v ní evidentně nejsme. Tento můj občanský názor navíc zesilují nevyjasněná zdravotní rizika tohoto očkování, o kterém se vede veřejný spor mezi našimi zdravotníky. Vojáci nemohou být považováni za pokusný vzorek, na němž se bude - bez jejich souhlasu - vakcína v praxi zkoušet. Dávám proto k úvaze jak ministru obrany, tak náčelníkovi generálního štábu, zda uvedené rozhodnutí nezmírnit a neponechat. “

Dostupné na http://www.klaus.cz/tiskova-sdeleni. [cit. 2013-06-11] 